\title{
ANALISIS UJI TARIK DAN METALOGRAFI SIFAT MEKANIK BESI TUANG KELABU (FC-20) DENGAN PROSES HEAT TREATMENT
}

\author{
Adriano Da Silva De Yesus \& Gatot Soebiyakto \\ Jurusan Teknik Mesin Universitas Widyagama Malang \\ Email:gtotop_bgt@yahoo.com.au
}

\begin{abstract}
ABSTRAK
Perkembangan ilmu pengetahuan dan teknologi saat ini membawa dampak yang begitu besar bagi perkembangan teknologi,seiring dengan kemajuan dunia industri, terutama industri di bidang otomotif dan permesinan. Berbagai kebutuhan terhadap material yang beraneka ragam telah memaksa manusia untuk berinovasi,. Sehingga material logam yang paling banyak digunakan di dunia industri adalah baja, karena baja memiliki keunggulan yaitu kekuatan yang tinggi, kemampukerasan yang baik dan relatif ulet. Pada perkembangannya penggunaan material baja diimbangi dengan semakin banyaknya pengunaan material besi cor. Hal ini terjadi karena besi cor memiliki beberapa keunggulan dibandingkan baja, yaitu merupakan bahan yang relatif murah, memiliki sifat mampu cor (castability) yang baik, dan juga memiliki sifat mampu mesin (machinability) yang relatif lebih baik dibandingkan dengan baja. Maka penelitian ini bertujuan untuk mengetahui peningkatan sifat mekanik gray cast iron ( FC-20) terhadap kekuatan tarik dan struktur makro dengan proses heat treatmant. Penelitian ini menggunakan besi cor kelabu FC 20, dengan pengujian pertama yaitu quenching metode pendinginan air garam, pendinginan air es dan pendinginan oli terhadap nilai kekuatan tarik dan struktur makro besi cor kelabu FC 20. Variasi temperatur pemanasan yang digunakan sebesar 6000C-7500C dengan penahanan waktu selama 45 menit/ 1 jam. Pengujian kedua sebagai pembanding dengan variasi besi cor kelabu FC 20 tanpa perlakuan. Hasil penelitian menunjukkan bahwa pada besi cor kelabu FC 20 di dapatkan hasil yang berbeda-beda, yaitu dimana pada besi cor FC-20 tanpa perlakuan lebih cenderung mengalami penurunan kekuatan tarik yaitu dengan jumlah harga rata-rata nilai kekuatan tarik tertinggi sebesar $23.14 \mathrm{~kg} / \mathrm{mm} 2$ dan nilai regangan lebih tinggi yaitu 10,23\% sedangkan pendinginan air garam lebih cenderung mengalami kenaikan kekuatan tarik yang sangat tinggi yaitu dengan jumlah harga rata-rata nilai kekuatan tarik tertinggi sebesar $30.23 \mathrm{kgf} / \mathrm{mm} 2$ dan mengalami penurunan nilai regangan yaitu sebesar 1.7\%, sedangkan pada variasi pendinginan air es memiliki rata-rata nilai kekuatan tarik tertinggi sebesar $27.75 \% \mathrm{kgf} / \mathrm{mm} 2$ dan mengalami kenaikan regangan yaitu sebesar $1.8 \%$. sedangkan pada variasi pendinginan oli hasil kekuatan tariknya naik lebih tinggi bila dibandingkan dengan pendinginan air es yaitu dengan rata rata nilai kekuatan tarik tertinggi sebesar 29 kgf/mm2 dan mengalami penurunan regangan yaitu sebesar $1.6 \%$.
\end{abstract}

\section{Kata kunci: Besi cor kelabu, Quenching, dan struktur makro.}

\section{PENDAHULUAN}

Perkembangan ilmu pengetahuan dan teknologi saat ini membawa dampak yang begitu besar bagi perkembangan teknologi, seiring dengan kemajuan dalam dunia industri, terutama industri di bidang otomotif dan permesinan. Berbagai kebutuhan terhadap material yang beraneka ragam telah memaksa manusia untuk berinovasi, baik dari pemilihan material sampai dengan pembaruan sifat - sifat material. Sehingga material logam yang paling banyak digunakan di dunia industri adalah baja, karena baja memiliki keunggulan yaitu kekuatan yang tinggi, kemampukerasan yang baik dan relatif ulet. Pada perkembangannya penggunaan material baja diimbangi dengan semakin banyaknya pengunaan material besi cor. Hal ini terjadi karena besi cor memiliki beberapa keunggulan dibandingkan baja, yaitu merupakan bahan yang relatif murah, memiliki sifat mampu cor (castability) yang baik, dan juga memiliki sifat mampu mesin (machinability) yang relatif lebih baik dibandingkan dengan baja.

Besi cor pada dasarnya merupakan paduan eutektik dari besi dan karbon. Dengan demikian temperature lelehnya relative lebih rendah, sekitar 1200 celcius. Temperature leleh yang rendah sangat menguntungkan, karena mudah dicairkan, sehingga pemakaian bahan bakar atau energi lebih hemat dan murah. Selain itu dapur peleburannya dapat di bangun dengan lebih sederhana.

Besi cor dapat diklasifikasikan menjadi beberapa jenis, diantaranya besi cor kelabu, besi cor nodular, besi cor mampu tempa dan besi cor putih. Besi cor nodular adalah salah satu jenis besi cor mampu tempa yang bentuk grafitnya bulat, kekuatan dan keuletannya menjadi lebih baik.

Permasalahan yang diangkat dalam penelitian ini adalah tentang besar perbedaan sifat mekanis tarik pada besi cor kelabu (gray cast iron) FC-20 sebelum dan sesudah pengujian berlangsung, dan perubahan struktur makro 
(ferrite, perlit, grafit) sebelum dan sesudah pengujian berlangsung.

Penelitian besi cor nodular telah dilakukan. Beberapa diantaranya digunakan sebagai dasar untuk mendukung pelaksanaan penelitian ini. Wahyu Purwo Raharjo dan Eko Surojo (2007) melakukan penelitian tentang pengaruh Temperatur Dan Waktu Austempering Terhadap Kekerasan ADI (Austempering ductile Iron) Hasil Austempering FCD-55.Penelitian ini menggunakan Besi Cor Nodular FCD-55 dengan kekuatan tarik sekitar $55 \mathrm{kgf} / \mathrm{mm} 2$. Besi cor nodular merupakan bahan baku yang sering digunakan dalam proses pengecoran logam selain besi cor kelabu. Sifat mekanik FCD-55 dapat ditingkatkan yaitu meliputi kekuatan, ketangguhan dan ketahanan ausnya dengan proses austempering. Dengan semakin baik sifat mekaniknya maka material yang dihasilkan dari proses austempering tersebut dapat digunakan untuk membuat komponen-komponen mesin yang menerima beban berat.

Galih Suhatmoko dan Nukman (2008) melakukan pengujiian Analisa Perlakuan Panas Austempering Pada Besi Tuang Nodular FCD-45 Terhadap Kekuatan Impak dan Kekerasanya, Prsoses perlakuan panas austemper yang dilakukan meliputi preheating (pemanasan awal) pada temperatur $6000 \mathrm{C}$ selama 30 menit, dilanjutkan dengan menaikkan temperatur hingga temperatur austenisasi 9000C selama 60 menit, kemudian temperatur diturunkan hingga temperatur austempering 3750C selama 30 menit. Spesimen didinginkan dalam dapur setelah proses austempering selesai. Dari hasil penelitian menunjukan bahwa pengaruh dari perlakuan panas austempering meningkatkan kekuatan impak dan kekerasanya. Kekuatan impak spesimen mengalami peningkatan sebesar $42,78 \%$ dari 30,52 J menjadi 53,34 J sedangkan kekerasan meningkat $71,71 \%$ dari 118,61 BHN menjadi 419,32 BHN. Untuk struktur mikro besi tuang nodular grafitnya berbentuk nodul (Bulatan), besi tuang nodular yang telah mengalami proses perlakuan panas austempering mengalami pengecilan bentuk nodul (bulatan) pada grafitnya dan jumlah nodul lebih merata daripada sebelum mengalami perlakuan panas.

Pramono (2011) melakukan pengujian karakteristik mekanik proses hardening baja AISI 1045 media quenching untuk aplikasi sprochet rantai. Pada baja AISI 1045 dilakukan pengerasan (hardening) untuk memperoleh sifat tahan aus dan kekerasan yang tinggi, dengan proses heat treatment (perlakuan panas), yang dilanjutkan dengan proses quenching, kekerasan yang dicapai tergantung pada temperatur pemanasan, holding time, dan laju pendinginan yang dilakukan pada laku panas. Kekerasan baja AISI 1045 yang dicapai pada proses perlakuan panas dilanjutkan quenching agitasi dengan tebal sampel dan volume air yang divariasikan, sehingga diperoleh kekerasan maksimum pada volume air 10 liter dengan nilai kekerasan rata-rata 59,62 HRC, sedangkan untuk nilai kekerasan rata-rata pada volume air 15 liter yaitu 58,56 HRC, untuk volume air 20 liter 57,62 HRC dan untuk volume air 25 liter yaitu 58,37 HRC.

\section{PERLAKUAN PANAS PADA BESI COR}

Heat Treatment adalah perlakuan panas kepada material/logam untuk memperoleh sifatsifat yang di inginkan, dengan jalan memanaskan sampai temperatur tertentu, untuk kemudian dilakukan pendinginan ataupun penambahan unsur tertentu, sehingga diperoleh bentuk struktur mikro, kekerasan / sifat yang diinginkan.

Melalui perlakuan panas yang tepat, tegangan dalam dapat dihilangkan, besar butir diperbesar atau diperkecil, ketangguhan ditingkatkan atau dapat dihasilkan suatu permukaan yang keras disekeliling inti yang ulet.

Maksud perlakuan panas tersebut secara garis besar menyangkut:

1. Meningkatkan kekerasan dan keuletan.

2. Menghilangkan tegangan dalam

3. Melunakkan Baja/besi.

4. Menormalkan keadaan logam biasa dari akibat pengaruh-pengaruh pengerjaan dan perlakuan panas sebelumnya.

5. Menghaluskan butir-butir kristal atau kombinasi dari maksud-maksud tersebut diatas

Proses perlakuan panas ada dua kategori, yaitu :

1. Softening (pelunakan) : adalah usaha untuk menurunkan sifat mekanik agar menjadi lunak dengan cara mendinginkan material yang sudah dipanaskan didalam tungku (annealing) atau mendinginkan dalam udara terbuka (normalizing). Contoh : annealing, normalizing, tempering.

2. Hardening (pengerasan) : adalah usaha untuk meningkatkan sifat material terutama kekerasan dengan cara celup cepat (quenching) material yang sudah dipanaskan ke dalam suatu media quenching berupa air, air garam, maupun oli. Contoh : surface hardening dan quenching.

\section{Hardening}

Hardening adalah perlakuan panas terhadap baja/besi dengan sasaran meningkatkan kekerasan alami baja/besi. Perlakuan panas menuntut pemanasan benda kerja menuju suhu pengerasan didaerah atau di atas daerah kritis dan pendinginan berikutnya secara cepat dengan kecepatan pendinginan kritis. Akibat penyejukan dingin dari daerah suhu pengerasan ini dicapailah suatu keadaan paksa bagi struktur besi yang 
membentuk kekerasan. Oleh karena itu maka proses pengerasan ini di sebut juga pengerasan kejut atau pencelupan langsung kekerasan yang tercapai pada kecepatan pendinginan kritis (martensit) ini diiringi kerapuhan yang besar dan tegangan pengejutan.

Pada setiap operasi perlakuan panas, laju pemanasan merupakan faktor yang penting. Panas merambat dari luar ke dalam dengan kecepatan tertentu bila pemanasan terlalu cepat, bagian luar akan jauh lebih panas dari bagian dalam oleh karena itu kekerasan di bagian dalam benda akan lebih rendah dari pada di bagian luar, dan ada nilai batas tertentu. Namun, air garam atau air akan menurunkan suhu permukaan dengan cepat, yang diikuti dengan penurunan suhu di dalam benda tersebut sehingga di peroleh lapisan keras dengan ketebalan tertentu.

\section{Quenching}

Quenching adalah proses pendinginan setelah mengalami pemanasan. Media quenching dapat berupa oli, air, air garam, dan lain-lain sesuai dengan material yang diquenching. Dimana kondisi sangat mempengaruhi tingkat kekerasan. Pada quenching proses yang paling cepat akan menghasilkan kekerasan tertinggi.

Jika suatu benda kerja diquench ke dalam medium quenching, lapisan cairan disekeliling benda kerja akan segera terpanasi sehingga mencapai titik didihnya dan berubah menjadi uap. Berikut adalah 3 tahap pendinginan :

\section{Tahap A (Vapor - Blanket Stage)}

Tahap ini benda kerja akan segera dikelilingi oleh lapisan uap yang terbentuk dari cairan pendingin yang menyentuh permukaan benda. Uap yang terbentuk menghalangi cairan pendingin menyentuh permukaan benda kerja. Sebelum terbentuk lapisan uap, permukaan benda kerja mengalami pendinginan yang sangat intensif. Dengan adanya lapisan uap, akan menurunkan laju pendinginan karena lapisan terbentuk dan akan berfungsi sebagai isolator. Pendinginan dalam hal ini terjadi efek radiasi melalui lapisan uap lama-kelamaan akan hilang oleh cairan pendingin yang mengelilinginya. Kecepatan menghilangkan lapisan uap makin besar jika viskositas cairan makin rendah. Jika benda kerja didinginkan lebih lanjut, panas yang dikeluarkan oleh benda kerja tidak cukup untuk tetap menghasilkan lapisan uap, dengan demikian tahap B dimulai.

\section{Tahap B (Vapor - Blanket Cooling Stage)}

Pada tahap ini cairan pendingin dapat menyentuh permukaan benda kerja sehingga terbentuk gelembung-gelembung udara dan menyingkirkan lapisan uap sehingga laju pendinginan menjadi bertambah besar.

\section{Tahap C (Liquid Cooling Stage)}

Tahap C dimulai jika pendidihan cairan pendingin sudah berlalu sehingga cairan pendingin tersebut pada tahap ini sudah mulai bersentuhan dengan seluruh permukaan benda kerja. Pada tahap ini pula pendinginan berlangsung secara konveksi karena itu laju pendinginan menjadi rendah pada saat temperature benda kerja turun. Untuk mencapai struktur martensit yang keras dari baja karbon dan baja paduan, harus diciptakan kondisi sedemikian sehingga kecepatan pendinginan yang terjadi melampaui kecepatan pendinginan kritis dari benda kerja yang diquench, sehingga transformasi ke perlit atau bainit dapat dicegah.

\section{Media Pendingin}

Untuk proses quenching kita melakukan pendinginan secara cepat dengan menggunakan media oli. Semakin cepat logam didinginkan maka akan semakin keras sifat logam itu. Karbon yang dihasilkan dari pendinginan cepat lebih banyak dari pendinginan lambat. Hal ini disebabkan karena atom karbon tidak sempat berdifusi keluar dan terjebak dalam struktur kristal dan membentuk struktur tetagonal yang ruang kosong antar atomnya kecil, sehingga kekerasanya meningkat.

Untuk mendinginkan bahan di kenal berbagai macam bahan.dimana untuk memperoleh pendinginan yang merata maka bahan pendinginan tersebut hampir semuanya di sirkulasi, contohnya yaitu :

\section{Air}

Air memberi pendinginan yang sangat cepat. Untuk memperbesar daya pendinginan air, maka kedalam air tersebut dilarutkan garam dapur dari 5 sampai $10 \%$.

\section{Minyak / Oli}

Minyak / oli memberi pendinginan yang cepat, oleh karena itu untuk keperluan ini minyak harus memenuhi berbagai macam persyaratan.

\section{Udara}

Udara memberi pendinginan yang perlahan-laha. Udara tersebut ada yang disirkulasi dan ada pula yang tidak disirkulasi.

\section{Garam}

Garam memberi pendinginan yang cepat dan merata. Garam tersebut terutama digunakan untuk proses Hardening.

\section{Holding Time (Waktu Tahan)}

Holding time dilakukan untuk mendapatkan kekerasan maksimum dari suatu bahan pada proses quenching dengan menahan pada temperatur pengerasan untuk memperoleh 
pemanasan yang homogen sehingga struktur austenitnya homogen. Pada proses pack carburizing holding time sangat diperlukan untuk menghasilkan kelarutan karbon pada besi cor, semakin lama holding timenya maka semakin banyak karbon yang berdifusi dengan besi.

\section{METODOLOGI}

Penelitian ini dilakukan di Laboratorium Uji Logam Univ. Merdeka Malang dengan variabel bebas penelitian adalah quenching air garam, air es dan oli, sedangkan variabel terikat meliputi uji kekuatan tarik, dan strukturmikro.

Prosedur pengujian dalam penelitian ini ada dua metode yaitu dengan pengujian tarik dan pengujian mikrostruktur.

\section{Prosedur uji tarik}

a. Menyiapkan besi tuang kelabu FC-20 sebanyak 3 buah sebagai benda uji tarik

b. Mengambil data awal setiap spesifikasi dari setiap besi cor sebelum mendapat perlakuan

c. Menaruh benda uji pada pegangan (grip) atas pegangan bawah pada mesin uji tarik

d. Menyalakan mesin uji tarik

e. Mengambil data akhir setelah mendapat perlakuan

\section{Prosedur Pengujian Metalografi}

Setelah semua spesimen dilakukan perlakuan panas dan tanpa perlakuan maka selanjutnya dilakukan pengujian metalografi. Pengujian metallografi dilakukan terhadap patahan hasil uji tarik. Selanjutnya pengujian ini akan menunjukkan pengaruh yang ditimbulkan oleh proses austempering terhadap struktur mikro spesimen tersebut dan dengan hasil pengujian ini dapat di ambil kesimpulan tentang perubahan sifat yang di alami material akibat proses heatreatmant. Adapun urutan dalam melakukan pengujian metalografi ini adalah sebagai berikut :

1. Menyiapkan besi cor FC-20 sebanyak 3 buah sebagai benda uji metalografi.

2. Proses pengamplasan pada permukaan benda bertujuan untuk menghaluskan permukaan benda dan meratakan bidang permukaan benda yang miring.

3. Proses pemolesan yang bertujuan untuk meningkatkan tingkat kehalusan yang maksimal pada permukaan benda uji .

4. Proses pengetsaan dilakukan dengan menggunakan asam pikral yang bertujuan untuk menunjukan adanya butiran - butiran kristal pada logam setelah pengambilan gambar.

\section{HASIL DAN PEMBAHASAN}

Data hasil pengujian tarik diolah untuk menghasilkan kekuatan tarik dan regangan. Data tersebut kemudian dijadikan diagram sebagaimana tampak pada Gambar 1 dan 2 . Selanjutnya dilakukan analisis mikrostruktur dengan hasil sebagaimana tampak pada Gambar 3 hingga 5.
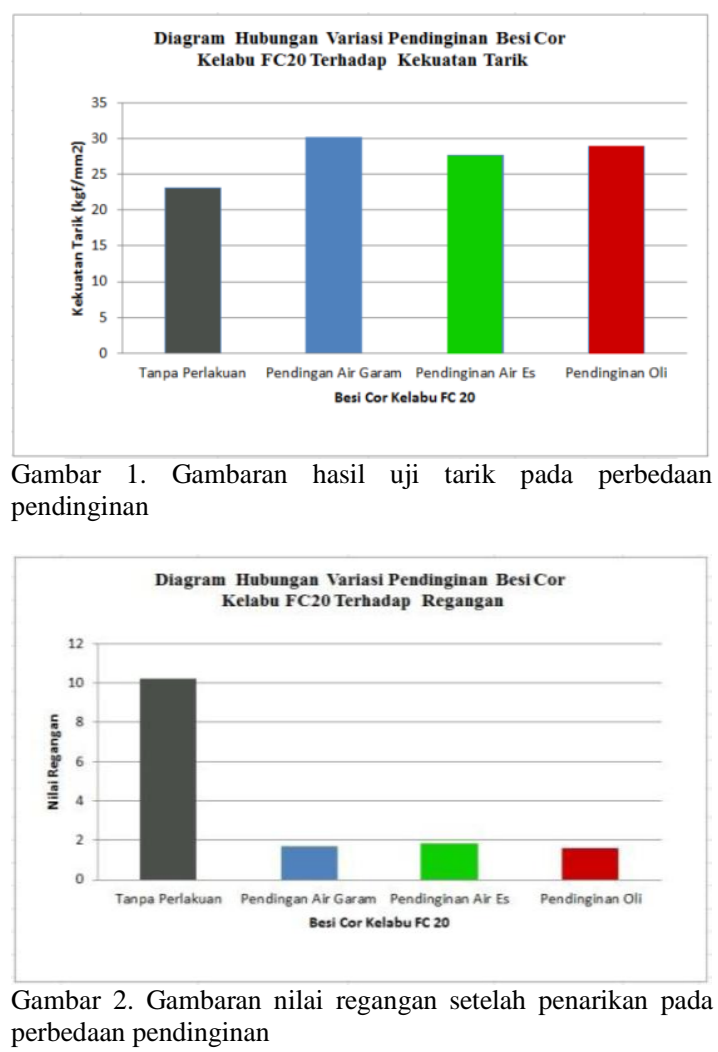

Dari hasil pengujian besi cor kelabu (FC20) terhadap kekuatan tarik dengan variasi tanpa perlakuan, pendinginan air garam, pendinginan air es dan pendinginan oli di dapatkan hasil yang berbeda-beda, yaitu dimana pada besi cor FC-20 tanpa perlakuan lebih cenderung mengalami penurunan kekuatan tarik yaitu dengan jumlah harga rata-rata nilai kekuatan tarik tertinggi sebesar $23.14 \mathrm{kgf} / \mathrm{mm} 2$ dan mengalami kenaikan regangan yaitu sebesar 10,23\%, sedangkan pendinginan air garam lebih cenderung mengalami kenaikan kekuatan tarik yang sangat tinggi yaitu dengan jumlah harga rata-rata nilai kekuatan tarik tertinggi sebesar $30.23 \mathrm{kgf} / \mathrm{mm} 2$ dan mengalami kenaikan regangan yaitu sebesar $1.7 \%$, sedangkan pada variasi pendinginan air es memiliki rata-rata nilai kekuatan tarik tertinggi sebesar $27.75 \% \mathrm{kgf} / \mathrm{mm} 2$ dan mengalami kenaikan regangan yaitu sebesar $1.8 \%$, sedangkan pada variasi pendinginan oli hasil kekuatan tariknya naik lebih tinggi bila dibandingkan dengan pendinginan air es yaitu dengan rata rata nilai kekuatan tarik tertinggi sebesar $29 \mathrm{kgf} / \mathrm{mm} 2$ dan mengalami penurunan regangan yaitu sebesar 1.6\%. Sehingga Pada pendinginan air garam, pendinginan air es dan pendinginan oli, hal ini dikarenakan pada saat pencelupan benda uji pada media pendinginan air garam telah mengalami 
perubahan kekuatan tarik dan regangan yang sangat cepat sehingga dapat mempengaruhi udara yang masuk, Akibat dari udara yang masuk akan mempengaruhi hasil dari suatu proses pendinginan. Sehingga menurut hasil analisa pengujian kekuatan tarik yang telah dilakukan, apabila semakin cepat logam didinginkan pada median pendingin yang bersifat sangat cepat maka akan semakin keras pula sifat logam tersebut. Karena karbon yang di hasilkan dari pendinginan cepat lebih banyak dari pendinginan lambat. Hal ini disebabkan karena atom karbon tidak sempat berdifusi keluar dan terjebak dalam struktur kristal dan membentuk struktur tetagonal yang ruang kosong antar atomnya kecil, sehingga kekerasanya meningkat.

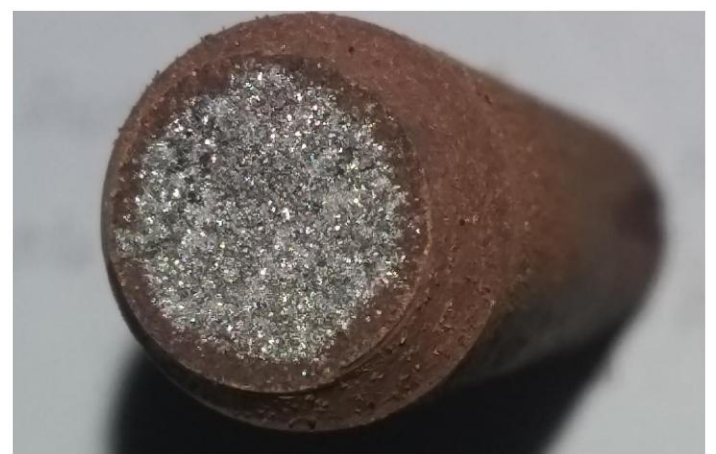

Gambar 3. Mikrostruktur spesimen pendinginan air garam

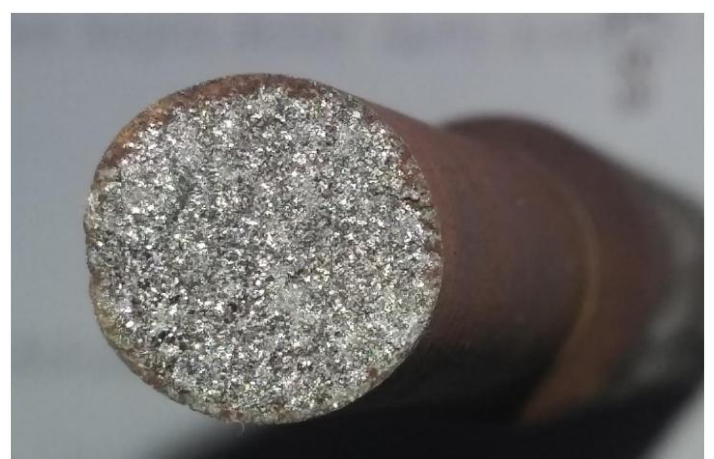

Gambar 4. Mikrostruktur spesimen pendinginan air es

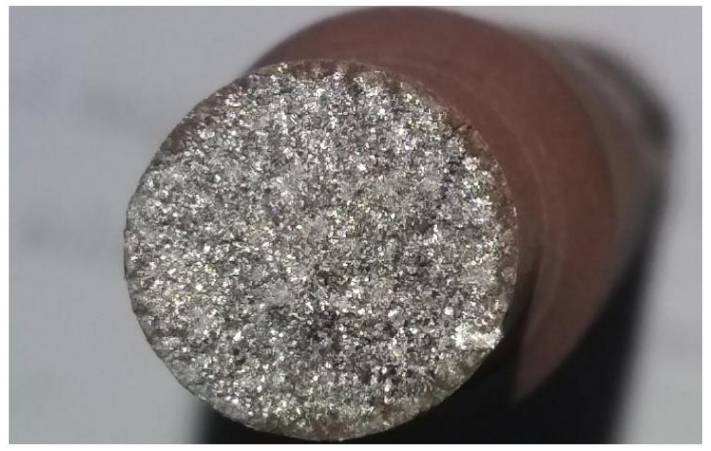

Gambar 5. Mikrostruktur spesimen pendinginan oli
Struktur mikro ketiga patahan hasil uji tarik spesimen yang mengalami perbedaan perlakuan tidak jauh menunjukkan perbedaan. Ketiganya menunjukkan tipe patahan getas yang mengindikasikan tingginya tingkat kekerasan logam uji. Hal ini sejalan dengan hasil analisis regangan yang menunjukkan bahwa regangan spesimen yang mengalami heat treatment jauh lebih rendah dari spesimen tanpa perlakuan, dengan nilai yang nyaris sama.

\section{KESIMPULAN}

Hasil penelitian menunjukkan bahwa proses pendinginan dengan media air garam, air es dan oli tidak menunjukkan perbedaan yang besar meskipun kekerasannya meningkat jauh dari kekerasan spesimen tanpa perlakuan. Hal ini didukung oleh hasil analisis mikrostruktur terhadap patahan hasil uji tarik.

\section{DAFTAR PUSTAKA}

Agus Pramono. 2011. Karakterisrik Mekanik Proses Hardening Baja Aisi 1045 Media Quenching Untuk Aplikasi Sprochet Rantai. Jurnal Ilmiah Teknik Mesin Vol. 5 No.1. April $2011(32-38) 32$

Pramuko, I. P. 2009. Peningkatan Kekakuan Baja Pegas Daun dengan Cara Quenching. Media Mesin. Vol. 10. No. 1. Hal 15-21. ISSN 14114348

Suprihanto, Agus; Umardani, Yusuf; Wibowo, Dwi Basuki (2005-01) Perbaikan Sifat Mekanis Besi Cor Kelabu Dengan Penambahan Unsur Crom Dan Tembaga Teknik Mesin Universitas Diponegoro Semarang

Suhatmoko, Galih and Nukman, Nukman (2008) Analisa Perlakuan Panas Austempering pada Besi Tuang Nodular FCD 45 terhadap Kekuatan Impak dan Kekerasannya. Jurnal Rekayasa Sriwijaya, 16 (2).

Vlack Lawrence H. Van. 1992. Ilmu dan Teknologi Bahan. Jakarta.Erlangga.

http://bobby-gunadarma.blogspot.co.id/2010 /09/tulisan2-ilmu-logam-pengecoranlogam.html

http://www.infometrik.com/2011/08/perlakuanpanas-logam-1-diagram-fasa

http://sonjaya45.wordpress.com/2010/03/13/besicor/

http://ardra.biz/metalurgi/besi-cor-cast-iron 